Dena Ali, ${ }^{1 *}$ Jeffrey M. Farber, ${ }^{1}$ JinHee Kim, ${ }^{2,3}$

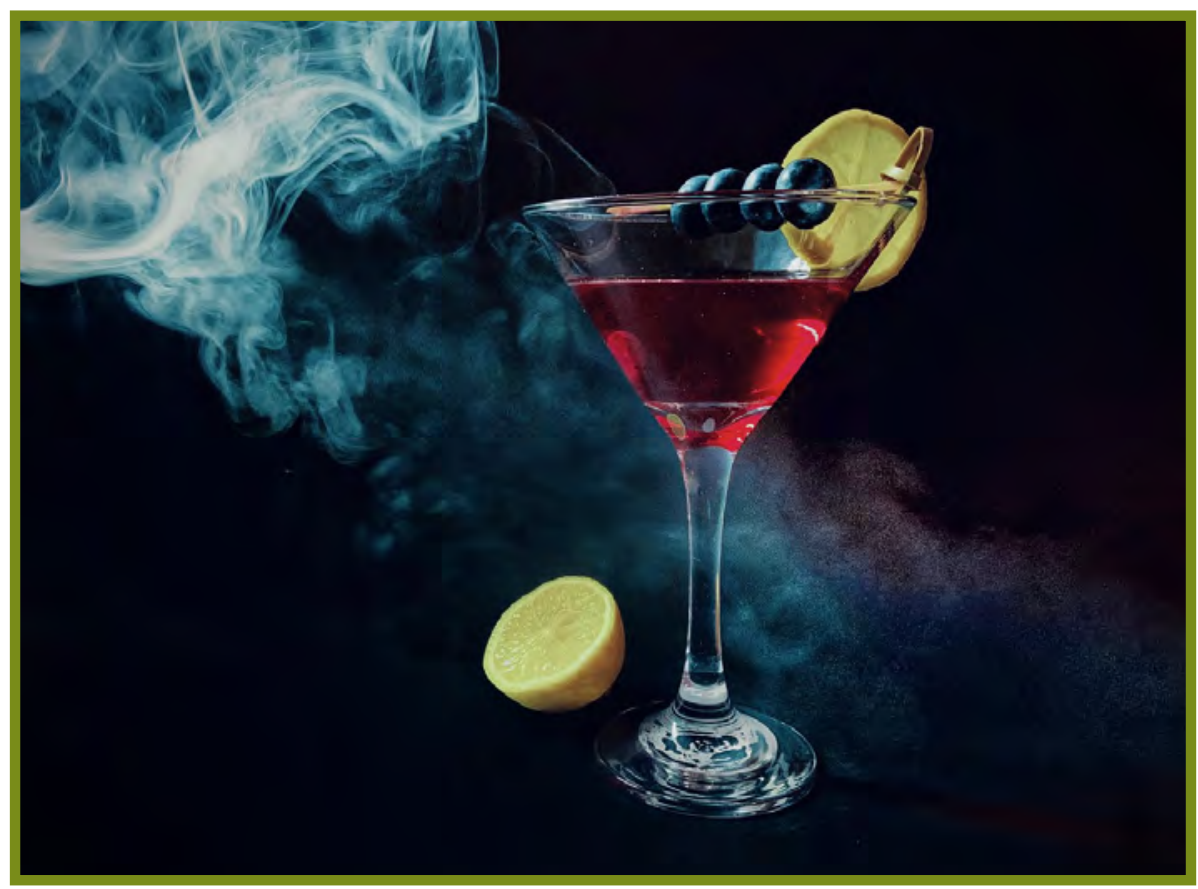

\title{
A Qualitative Risk Assessment of Liquid Nitrogen in Foods and Beverages
}

\section{ABSTRACT}

Smokey liquid nitrogen $\left[\mathrm{LN}_{2}\right]$ infusions are one of the latest eye-catching food trends. With its ability to create fog-like effects and flash freeze foods, LN $_{2}$ has become popular for use in ice cream, snacks, and cocktails recently. Although perceived to be harmless, there are incidents of consumers suffering adverse health effects after consuming foods prepared with $\mathbf{L N}_{2}$. Thus, a qualitative risk assessment was undertaken to estimate the potential risks to consumers. Through an analysis of gray and scientific literature, case reports related to inhalation, ingestion, and contact with $\mathrm{LN}_{2}$ were reviewed for relevant information. It was found that inhalation of $\mathrm{LN}_{2}$ vapors could potentially cause rare, but serious, injuries such as respiratory distress and asphyxia. Ingestion injuries, which typically result after consuming $\mathrm{LN}_{2}$ before it fully evaporates, often include gastrointestinal barotrauma and rupture. Lastly, when skin or tissues come in contact with $\mathrm{LN}_{2}$ for more than a short period of time, frostbite can occur. To reduce the risks posed to consumers, it is recommended that (i) vendors are properly trained to handle and serve $\mathrm{LN}_{2}$, (ii) patrons are given clear instructions on how to safely consume such treats, and (iii) regulatory agencies put appropriate regulatory interventions into action as needed.

\section{INTRODUCTION}

Ambient air is composed of approximately $78 \%$ nitrogen gas (26). Through a process called fractional distillation, nitrogen gas in the air can be separated from the other components of air and converted into its liquid state (3, 26). Nitrogen in its liquid form is referred to as liquid nitrogen $\left(\mathrm{LN}_{2}\right)$ and is characterized as being inert, colorless, noncorrosive, and nonflammable $(1,26)$. For nitrogen to remain in its liquid state, it must be kept at very high pressures and extremely low temperatures (3). If $\mathrm{LN}_{2}$ comes in contact with anything above its boiling point $\left(-196^{\circ} \mathrm{C}\right.$ or $\left.-320.1^{\circ} \mathrm{F}\right)$, it will transform back into nitrogen gas $(3,26)$.

Due to its cold temperature, $\mathrm{LN}_{2}$ has become widely adopted for its rapid cooling and freezing applications (38). From flash freezing foods to preserving biological specimens, $\mathrm{LN}_{2}$ serves many different functions in various industries 
(38). Thus, its use has been well documented in industries such as health care, sports, rubber and plastics, research, construction, music, electronics, food and beverage, automotive, and pharmaceutical and metal manufacturing $(1,38)$.

Dry ice, known as solid CO2, is often confused with $\mathrm{LN}_{2}$. However, when $\mathrm{LN}_{2}$ reaches its boiling point temperature of $-196^{\circ} \mathrm{C}$, it undergoes vaporization (transition from liquid to gas) (3). In contrast, dry ice undergoes sublimation (transition from solid to gas) when it reaches a temperature of $-78.5^{\circ} \mathrm{C}$ (3). Although both can be used for cryogenic applications, different industries prefer to use one over the other depending on their temperature requirements, costs, and ease of use. In retail food settings, $\mathrm{LN}_{2}$ tends to be used more often than dry ice, which is why this paper primarily focuses on $\mathrm{LN}_{2}$.

In the food and beverage industry, the commercial use of $\mathrm{LN}_{2}$ as a coolant is well established (3). It is an ideal freezing agent because of its ability to reduce chemical and microbial spoilage in foods and beverages, while retaining optimum flavor and quality $(1,34)$. This is accomplished by using the cold temperature of $\mathrm{LN}_{2}$ to help slow heat production and oxidation during processing, packaging, and shipping (3). Besides chilling to prolong the shelf life of various foods like meats, dairy products, produce, condiments, sauces, and desserts, $\mathrm{LN}_{2}$ also has many other applications (3). These include adding pressure to bottled and canned beverages to allow for stronger and more rigid packaging, using freezing processes to grind meats and spices, and speeding up cooling during product layering to prevent the blending of constituent parts $(3,18)$.

Apart from using $\mathrm{LN}_{2}$ as a food processing and preservation aid, retail food and beverage establishments are now capitalizing on trends that involve using it in more unconventional ways. Such trends include applying $\mathrm{LN}_{2}$ to foods or glassware just prior to consumption, to create aesthetically pleasing smoke-like effects and novelty frozen desserts like ice cream in an instant $(3,36)$. Such effects occur because $\mathrm{LN}_{2}$ is extremely cold, and it produces a visible fog upon evaporation in warmer air settings (2). This method of combining scientific techniques with culinary art to prepare and present food is sometimes referred to as molecular gastronomy $(3,8)$. Culinary applications of $\mathrm{LN}_{2}$ include flash freezing foods and liquids to create garnishes, crafting unique shapes out of food, improving cooking processes, manipulating textures, and enhancing visual appeal $(3,8)$.

To consumers, these novelty foods and beverages seem like harmless fun. However, there is limited awareness about the potential health risks $\mathrm{LN}_{2}$ poses to consumers if foods or liquids are served directly after the application of $\mathrm{LN}_{2}$. When used in manufacturing as a processing aid, the risks are minimal because, by the time the product reaches the consumer, it is no longer as cold and the $\mathrm{LN}_{2}$ has fully evaporated (36). However, that is not always the case when it is applied to desserts and drinks at the point of purchase. Consequently, case reports are now emerging of patrons suffering acute, sometimes severe, injuries after improper ingestion of $\mathrm{LN}_{2}$. Therefore, from a public health perspective, research on this topic is important to identify and reduce any risks that may impact the health and well-being of consumers. To evaluate the likelihood of risk associated with $\mathrm{LN}_{2}$ consumption, a literature review and qualitative risk assessment was performed.

\section{METHODS}

The focus of the search strategy for this systematic review was to identify, extract, and analyze data from the literature that was most relevant to $\mathrm{LN}_{2}$ consumption. This began with a comprehensive search for scholarly publications and clinical case reports in the databases Ovid MEDLINE, Web of Science, and TOXNET. An Internet search on Google Scholar was also performed to obtain additional scholarly resources on $\mathrm{LN}_{2}$. These searches were conducted using the following key words, truncations, and Boolean operator combinations: ("liquid nitrogen.m_titl.") AND ("drink*.ti,ab." OR "beverage*.ti,ab” OR "cocktail*. ti,ab."), ("ingestion*.ti,ab." OR "consumption*.ti,ab.” OR "inhalation*,ti,ab."), ("injury*.ti,ab." OR "risk*.ti,ab." OR “danger*.ti,ab.” OR “effect*.ti,ab.”), (“frostbite*.ti,ab.”), ("asphyxiation*.ti,ab."), ("ice cream*.ti,ab." OR "snack*. ti,ab,"), and ("barotrauma*.ti,ab." OR "gastric perforation*. ti,ab." OR "pneumoperitoneum*.ti,ab.”). A more detailed outline of this search strategy can be found in Appendix A. Because studies on $\mathrm{LN}_{2}$ consumption are limited, search restrictions on language, geographical location, experimental design, and dates were not applied. Cases of $\mathrm{LN}_{2}$ exposure via inhalation, ingestion, or physical contact in nonfood settings were also reviewed for relevant information. When non-English articles that were related to $\mathrm{LN}_{2}$ consumption were found, Google Translate was used to interpret the findings into English. Additional articles were also found by scanning through the reference sections of articles identified in the search. Furthermore, to address potential research gaps and gather additional evidence on $\mathrm{LN}_{2}$ consumption, gray literature sources were also reviewed. These resources were retrieved from Google using various combinations of the following search terms: "liquid nitrogen," "treats," "snacks," "ice cream," "cocktails," "dessert," "dangers," "risks," "regulations," and "national/international food surveys." Due to the plethora of search results generated, information was only collected from the top 100 search results. They consisted of national and international food policy statements, government publications, newspaper articles, statistical reports, and other Web-based publications. See Appendix B for more information regarding the websites and databases used to retrieve gray literature. Overall, a total of 43 peerreviewed and non-peer-reviewed sources were synthesized for this review. 


\section{HAZARD IDENTIFICATION}

Although it is not common for $\mathrm{LN}_{2}$ to be applied to foods and beverages immediately before consumption, this practice has been gaining popularity in recent years $(3,36)$. Thus, case reports of people suffering from food-related injuries are beginning to appear $(3,36)$. Whereas cases are still rare, some of the injuries being reported have been quite severe, making this food trend a major cause for concern. Despite limited research in this area, this review of the literature revealed several health outcomes that may be associated with improper ingestion and handling of $\mathrm{LN}_{2}$. These are described in further detail in the following subsections. Although not all of these have been associated with exposure through foods and beverages, they provide information that is helpful in reducing possible $\mathrm{LN}_{2}$ risks to consumers and food handlers.

\section{Potential health outcomes associated with $\mathrm{LN}_{2}$ inhalation}

Nitrogen gas is a simple asphyxiant (26). In the event of a spill or leak in an enclosed area at room temperature, $\mathrm{LN}_{2}$ will evaporate and displace some of the oxygen in the air (3, 26). Without proper ventilation systems in place, individuals can become oxygen deprived if nitrogen levels in the air surpass $88 \%$ (26). This can lead to asphyxiation and is very dangerous because it may occur without warning and may potentially result in death $(19,20,25)$. Although this is not a risk for consumers, it may be a risk for food handlers working with large amounts of $\mathrm{LN}_{2}$ in a small room.

\section{Potential health outcomes associated with $\mathrm{LN}_{2}$ contact}

$\mathrm{LN}_{2}$ can cause severe thermal damage to the skin, eyes, and internal organs if not handled safely $(26,31)$. Examples of thermal-related injuries that may result following contact with $\mathrm{LN}_{2}$ include frostbite, blisters, ulcers, edema, and tissues necrosis (9). However, the severity of injury is dependent on the duration and area of contact. In most cases, injury occurs when bare skin and other exposed tissues come in contact with $\mathrm{LN}_{2}$ for more than a few seconds (26). For example, this can happen if individuals hold $\mathrm{LN}_{2}$-coated treats in their mouths for too long, or if the snack sticks to their gums. In other instances, individuals can be fully covered and wearing protective gloves but can still end up with thermal injuries after handling or working with $\mathrm{LN}_{2}$ (31). Thus, both direct and indirect exposure to $\mathrm{LN}_{2}$ should be avoided to prevent injury.

Brief contact with small amounts, e.g., 2 to $3 \mathrm{~mL}$ of $\mathrm{LN}_{2}$, however, does not always result in cryogenic injuries (2, $3)$. The reason for this has to do with a phenomenon called the Leidenfrost effect $(2,15)$. To illustrate this effect, one can envision $\mathrm{LN}_{2}$ as a droplet encountering a surface with a temperature far above its boiling point (7). When this occurs, the $\mathrm{LN}_{2}$ rapidly starts to evaporate and pressure from the vapor builds up as it tries to escape from beneath the droplet (7). At a certain level of pressure, the vapors elevate the droplet, forming an insulating film of vapor between the droplet and the surface $(2,3,7)$. As a result, this insulating film creates a barrier between the two surfaces, which causes a reduction in thermal transfer and injury (2).

\section{Potential health outcomes associated with $\mathrm{LN}_{2}$ ingestion}

When $\mathrm{LN}_{2}$ is added to desserts and drinks immediately before consumption, the belief is that it will evaporate and, therefore, pose no harm to customers (36). Unfortunately, this is not always the case because sometimes there will be residual $\mathrm{LN}_{2}$ that remains on the bottom of a serving container (11). In addition, $\mathrm{LN}_{2}$ is tasteless (26). Thus, if consumers are not instructed to wait before the $\mathrm{LN}_{2}$ completely vaporizes, they might accidentally ingest it without realizing it (3).

The most serious injury faced after ingesting $\mathrm{LN}_{2}$ is gastrointestinal barotrauma, which develops due to an increase in pressure within the stomach $(2,10,21-23,30$, 41-43). This occurs because, when $\mathrm{LN}_{2}$ enters the body, it immediately begins to evaporate upon contact with surface temperatures higher than its boiling point (39). Furthermore, as the $\mathrm{LN}_{2}$ travels from the mouth to the esophagus and into the stomach, the vapors that form along the way can lead to a large increase in pressure (39). The reason for this is that $\mathrm{LN}_{2}$ has a liquid-to-gas volume ratio of 1:694 $(2,30)$. This means that, when $\mathrm{LN}_{2}$ evaporates, its volume will increase by about 700 times within the body. As a result, patients may experience severe and painful abdominal distension following ingestion, because of the increase in volume and pressure within the gastrointestinal tract. (2). This rise in pressure typically leads to tissue necrosis and gastric rupture in the lesser curvature of the stomach, which requires surgery to fix (30).

\section{Potential health outcomes associated with biological contamination}

$\mathrm{LN}_{2}$ can also serve as an effective storage medium for pathogens (29). Microorganisms that can potentially survive after being cryopreserved by $\mathrm{LN}_{2}$ include bacteria, fungi, yeasts, and viruses $(29,35)$. Examples of microorganisms that have been found in $\mathrm{LN}_{2}$ tanks used to store biological specimens include Escherichia coli, Bacillus cereus, Mucor spp., Staphylococcus spp., and Pseudomonas aeruginosa, some of which can be spread through unhygienic practices (29). Although there have not been any reported incidents of consumers coming into contact with biological hazards from $\mathrm{LN}_{2}$ in their foods and beverages, it is still a potential hazard.

\section{HAZARD CHARACTERIZATION}

Given its relatively new applications in the retail food and beverage industry, no definitive dose-response relationships have been established for ingesting, inhaling, or coming into contact with $\mathrm{LN}_{2}$. However, based on the data available, it is apparent that the severity of injury is dependent upon the duration and area of contact, as well as the volume of $\mathrm{LN}_{2}$ one comes into contact with. For example, larger amounts of 
$\mathrm{LN}_{2}$ and longer contact times are more likely to be associated with more severe injuries. The following sections provide more information on the relative doses needed to elicit a response after ingestion, inhalation, or physical contact with $\mathrm{LN}_{2}$.

\section{Ingestion}

Almost $80 \%$ of the case reports related to $\mathrm{LN}_{2}$ ingestion did not identify the quantities of $\mathrm{LN}_{2}$ consumed. Among the few that did, subjects who suffered gastric perforations after $\mathrm{LN}_{2}$ consumption ingested anywhere from 15 to $30 \mathrm{~mL}$ of $\mathrm{LN}_{2}(2,22,41)$. Given the limited number of reports, there is considerable uncertainty regarding how much $\mathrm{LN}_{2}$ would need to be ingested to produce injury.

\section{Inhalation}

In all of the cases of thermal injury due to $\mathrm{LN}_{2}$ inhalation, the dose levels were not provided. In general, anyone is susceptible to asphyxiation once sufficient amounts of $\mathrm{LN}_{2}$ evaporate and cause oxygen levels to fall below $12 \%$ (19). However, when it comes to other inhalation-related injuries like asthma attacks, not everyone will experience distress to the same extent. Thus, whether or not $\mathrm{LN}_{2}$-induced injuries will occur depends on the dose, an individual's health status, and the environment in which it is inhaled.

\section{Physical contact}

Likewise, many of the studies describing cases of external or internal contact with $\mathrm{LN}_{2}$ (e.g., touching $\mathrm{LN}_{2}$ with one's hands or tongue) also did not make any reference to dose levels. However, a common theme observed was that injury severity was more dependent on the duration of exposure to $\mathrm{LN}_{2}$ rather than the extent of $\mathrm{LN}_{2}$ contact.

\section{Exposure Assessment \\ Potential sources of exposure}

With the help and influence of social media, consumer interest in $\mathrm{LN}_{2}$-infused foods has been on the increase. As a result, a variety of food and catering establishments such as restaurants, shopping centers, kiosks, bars, nightclubs, festivals, and fairs now offer these desserts and beverages $(3,36)$. Some of the more well-known treats and beverages prepared with $\mathrm{LN}_{2}$ include fog-emitting cocktails, instant ice creams, and billowing smoke snacks comprised of cereal puffs, donuts, or cookies, commonly referred to as Dragon's Breath, Heaven's Breath, or Nitro Puffs $(3,36) . \mathrm{LN}_{2}$ can also be used to create garnishes from fresh herbs or berries, prevent the overcooking of burgers, and prepare a variety of other smoke-emitting dishes (12).

\section{Prevalence and populations exposed}

Due to how popular these $\mathrm{LN}_{2}$-infused specialty desserts and beverages have become, they are now being served worldwide, but primarily in larger cities $(3,9,21,30)$. Although there is widespread potential for exposure to $\mathrm{LN}_{2}$ infused foods and beverages, some age groups will come into contact with certain food products more than others. For example, whereas $\mathrm{LN}_{2}$-infused ice creams and snacks are available to the general population, they typically appeal more to children, adolescents, and young adults, and only adults would be permitted to drink alcoholic beverages made with $\operatorname{LN}_{2}(21,27,30)$.

\section{Likelihood of exposure}

At present, comprehensive data on the use of $\mathrm{LN}_{2}$ served in retail food and beverage settings are nonexistent. To estimate the likelihood of exposure to foods that may be prepared with $\mathrm{LN}_{2}$, general food consumption patterns in Canada and the United States were analyzed. When Americans were asked to partake in a "24-hour dietary recall" for the 2015 to $2016 \mathrm{Na}$ tional Health and Nutrition Examination Survey, the percentage of cereals, baked goods, ice creams, and beverages being consumed was less than $10 \%$ for each (6). Because only a relatively small percentage of these foods are likely to be prepared using $\mathrm{LN}_{2}$, the number of people or percentage of the population exposed is likely to be small. Moreover, according to the 2014 to 2015 Canadian Foodbook Report, people tend to consume ice cream and cereals more frequently during the warmer months of the year (16). Because these treats are often served cold, exposure is estimated to be higher during the warmer seasons than the colder seasons (16). In addition, many of these novelty foods are often sold at pop-up events or annual festivals, which implies that consumers who do consume these treats would not do so very often $(13,14)$. However, the probability of exposure will vary depending on the region because some business chains run all year long and are typically located in major cities.

Note that the survey findings used for this analysis might not be an accurate representation of the entire population because the food consumption histories would have been subject to recall, response, and proxy bias. In addition, individuals without a landline or cell phone number (e.g., individuals in correctional institutions) were excluded from the telephone surveys and were, thus, not accounted for. Nevertheless, because very few establishments actually serve these specialty treats, the overall exposure to $\mathrm{LN}_{2}$-infused foods is presumed to be low. Although individuals may also be exposed to $\mathrm{LN}_{2}$ in nonretail food settings (e.g., schools, homes, etc.), these types of encounters are very rare $(23,43)$. Additionally, $\mathrm{LN}_{2}$ is not readily available for purchase at most stores because very few specialty retailers and distributors sell the agent.

\section{Summary of adverse effects attributable to $\mathrm{LN}_{2}$-infused foods and beverages \\ A total of nine peer-reviewed and eight non-peer- reviewed reports related to $\mathrm{LN}_{2}$ consumption were found and summarized in Tables 1 and 2, respectively. Among the 17 cases, 10 resulted in gastric perforations and eight in cold burn injuries; seven cases reported experiencing respiratory difficulties.}




\section{TABLE 1. Peer-reviewed case reports of $\mathrm{LN}_{2}$ exposure and/or consumption}

\begin{tabular}{|c|c|c|c|c|c|c|}
\hline $\begin{array}{c}\text { Case } \\
\#\end{array}$ & $\begin{array}{l}\text { Setting \& } \\
\text { Location }\end{array}$ & Case Type & $\begin{array}{l}\text { Sex \& } \\
\text { Age } \\
\text { (Years) }\end{array}$ & Details of Incident & Clinical Manifestation & Reference \\
\hline 1 & $\begin{array}{c}\text { School - } \\
\text { United States }\end{array}$ & Ingestion & $\begin{array}{c}\text { Male - } \\
15\end{array}$ & $\begin{array}{l}\text { Subject ingested } \\
\text { approximately } 30 \mathrm{~mL} \text { of } \\
\mathrm{LN}_{2} \text { while preparing ice } \\
\text { cream during a science } \\
\text { experiment. }\end{array}$ & $\begin{array}{l}\text { - Seizure } \\
\text { - Distended abdomen } \\
\text { - Massive pneumoperitoneum } \\
\text { - Minimal pneumomediastinum } \\
\text { - } 10 \text { cm perforation (lesser curvature of stomach) } \\
\text { - Tissue necrosis near perforation }\end{array}$ & (2) \\
\hline 2 & $\begin{array}{l}\text { N/A- } \\
\text { Australia }\end{array}$ & Ingestion & $\begin{array}{c}\text { Female } \\
-30\end{array}$ & $\begin{array}{l}\text { Subject placed cookie } \\
\text { coated with } \mathrm{LN}_{2} \text { in her } \\
\text { mouth and blew on it to } \\
\text { produce a "cauldron-like" } \\
\text { effect before consuming it. }\end{array}$ & $\begin{array}{l}\text { - Mild burning sensation in the mouth } \\
\text { - Second-degree intraoral frostbite that } \\
\text { resulted in blisters and ulcers in the lower } \\
\text { labial mucosa }\end{array}$ & (9) \\
\hline 3 & $\begin{array}{c}\text { Amusement } \\
\text { park - Asia }\end{array}$ & Ingestion & $\begin{array}{c}\text { Male - } \\
13\end{array}$ & $\begin{array}{l}\text { Subject ingested a cookie } \\
\text { that had liquid nitrogen } \\
\text { applied to it. }\end{array}$ & $\begin{array}{l}\text { - Severe abdominal pain } \\
\text { - Distended abdomen } \\
\text { - Shortness of breath } \\
\text { - Heart rate: } 120 \text { beats } / \text { min } \\
\text { - Large volume pneumoperitoneum } \\
\text { - Abnormal white blood cell count } \\
\text { ( } 21,400 / \mu \mathrm{L}) \\
\text { - Multiple erythemas } \\
\text { (lesser curvature of stomach) } \\
\text { - } 4 \text { cm perforation (lesser curvature of stomach) }\end{array}$ & (21) \\
\hline 4 & $\begin{array}{l}\mathrm{N} / \mathrm{A}- \\
\text { Europe }\end{array}$ & Ingestion & $\begin{array}{c}\text { Male - } \\
28\end{array}$ & $\begin{array}{l}\text { Subject ingested } 15 \mathrm{~mL} \\
\text { of } \mathrm{LN}_{2} \text { in an attempt to } \\
\text { "produce an impressive burp." }\end{array}$ & $\begin{array}{l}\text { - Severe abdominal distension } \\
\text { - Subcutaneous emphysema } \\
\text { - Gastric rupture (lesser curvature of stomach) }\end{array}$ & (22) \\
\hline 5 & $\begin{array}{c}\text { School - } \\
\text { United States }\end{array}$ & Ingestion & $\begin{array}{c}\text { Male - } \\
13\end{array}$ & $\begin{array}{l}\text { Subject ingested a smoke- } \\
\text { emitting blend of orange } \\
\text { crystals and } \mathrm{LN}_{2} \text { during a } \\
\text { science experiment. }\end{array}$ & $\begin{array}{l}\text { - Burning sensation in the throat } \\
\text { - Severe abdominal pain } \\
\text { - Distended abdomen } \\
\text { - Shortness of breath } \\
\text { - Mild respiratory acidosis } \\
\text { - Subcutaneous emphysema } \\
\text { - Two small perforations } \\
\text { (lesser curvature of stomach) }\end{array}$ & (23) \\
\hline 6 & $\begin{array}{l}\text { Licenced } \\
\text { drinking } \\
\text { establishment } \\
\text { - Europe }\end{array}$ & Ingestion & $\begin{array}{c}\text { Female } \\
-18\end{array}$ & $\begin{array}{l}\text { Subject ingested an } \\
\text { alcoholic beverage that was } \\
\text { prepared with } \mathrm{LN}_{2} \text {. }\end{array}$ & $\begin{array}{l}\text { - Severe abdominal pain } \\
\text { - Distended abdomen } \\
\text { - Shortness of breath } \\
\text { - Elevated white cell count: }\left(30.7 \times 10^{9} / \mathrm{L}\right) \\
\text { - Tachycardia } \\
\text { - Large volume pneumoperitoneum } \\
\text { - Free intra-abdominal fluid } \\
\text { - Erythema (fundus of the stomach) } \\
\text { - } 4 \text { cm perforation (lesser curvature of stomach) } \\
\text { - Necrosis and haemorrhage surrounding } \\
\text { perforation site } \\
\text { - Damage was so severe, a complete } \\
\text { gastrectomy had to be undertaken }\end{array}$ & (30) \\
\hline
\end{tabular}




\section{TABLE 1. Peer-reviewed case reports of $L N_{2}$ exposure and/or consumption (cont.)}

\begin{tabular}{|c|c|c|c|c|c|c|}
\hline $\begin{array}{c}\text { Case } \\
\#\end{array}$ & $\begin{array}{l}\text { Setting \& } \\
\text { Location }\end{array}$ & Case Type & $\begin{array}{c}\text { Sex \& } \\
\text { Age } \\
\text { (Years) }\end{array}$ & Details of Incident & Clinical Manifestation & Reference \\
\hline 7 & $\begin{array}{c}\mathrm{N} / \mathrm{A}- \\
\text { United Sates }\end{array}$ & Ingestion & $\begin{array}{c}\text { Male - } \\
19\end{array}$ & $\begin{array}{l}\text { Subject knowingly ingested } \\
\text { an unknown amount of } \\
\mathrm{LN}_{2} \text { after being dared to do } \\
\text { so by friends. }\end{array}$ & $\begin{array}{l}\text { - Abdominal pain } \\
\text { - Distended abdomen } \\
\text { - Mild respiratory difficulty } \\
\text { - White blood cell count: } 16,500 / \mu \mathrm{L} \\
\text { - Mild erythema (tongue and oropharynx) } \\
\text { - Massive pneumoperitoneum } \\
\text { - No perforation }\end{array}$ & (39) \\
\hline 8 & $\mathrm{~N} / \mathrm{A}-A s i a$ & Ingestion & $\begin{array}{c}\text { Male - } \\
17\end{array}$ & $\begin{array}{l}\text { Subject drank about } \\
30 \mathrm{~mL} \text { of orange juice } \\
\text { mixed with } \mathrm{LN}_{2} \text {. }\end{array}$ & $\begin{array}{l}\text { - Severe abdominal pain } \\
\text { - Distended abdomen } \\
\text { - Slightly elevated white blood cell count } \\
\text { - Pneumoperitoneum } \\
\text { - Pneumomediastinum } \\
\text { - } 3 \mathrm{~cm} \text { perforation (lesser curvature of stomach) }\end{array}$ & (41) \\
\hline 9 & $\begin{array}{c}\text { Subject's } \\
\text { home - Asia }\end{array}$ & Ingestion & $\begin{array}{c}\text { Male - } \\
25\end{array}$ & $\begin{array}{l}\text { Subject ingested a } \\
\text { beverage containing } \mathrm{LN}_{2} \\
\text { prepared at home. }\end{array}$ & 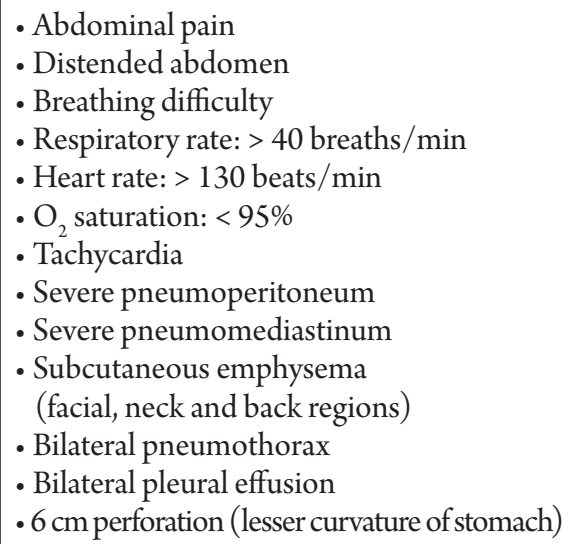 & (43) \\
\hline
\end{tabular}




\section{TABLE 2. Non peer-reviewed case reports of $\mathrm{LN}_{2}$ exposure and/or consumption}

\begin{tabular}{|c|c|c|c|c|c|c|}
\hline $\begin{array}{c}\text { Case } \\
\#\end{array}$ & $\begin{array}{l}\text { Setting \& } \\
\text { Location }\end{array}$ & Case Type & $\begin{array}{l}\text { Sex \& } \\
\text { Age } \\
\text { (Years) }\end{array}$ & Details of Incident & Clinical Manifestations & Reference \\
\hline 10 & $\begin{array}{l}\text { Drinking } \\
\text { Establishment } \\
\text { - Asia }\end{array}$ & Ingestion & $\begin{array}{l}\text { Male - } \\
\quad 30\end{array}$ & $\begin{array}{l}\text { Subject rapidly ingested } \\
\text { a cocktail containing } \mathrm{LN}_{2} \\
\text { while it was still emitting } \\
\text { smoke. }\end{array}$ & $\begin{array}{l}\text { - Severe pain } \\
\text { - Swollen abdomen } \\
\text { - Difficulty breathing } \\
\text { - Abnormal heart rate, blood pressure and } \\
\mathrm{O}_{2} \text { saturation } \\
\text { - Elevated level of lactic acid } \\
\text { - Abdominal free air } \\
\text { - Large gastric perforation } \\
\text { (middle and lower section of the stomach) } \\
\text { - Tissue damage near perforation }\end{array}$ & (10) \\
\hline 11 & $\begin{array}{l}\text { Night Market } \\
- \text { Asia }\end{array}$ & $\begin{array}{l}\text { Improper } \\
\text { handling }\end{array}$ & $\begin{array}{l}\text { Male - } \\
15\end{array}$ & $\begin{array}{l}\text { Subject emptied cup } \\
\text { containing Dragon's Breath } \\
\text { cookies and some residual } \\
\text { drops of } \mathrm{LN}_{2} \text { into the palm } \\
\text { of his hand. }\end{array}$ & $\begin{array}{l}\text { - Cold burns and blisters (palm of hand) } \\
\text { - Swollen palm }\end{array}$ & (11) \\
\hline 12 & $\begin{array}{l}\text { Local Shop - } \\
\quad \text { Asia }\end{array}$ & Ingestion & $\begin{array}{l}\text { Female } \\
-N / A\end{array}$ & $\begin{array}{l}\text { Subject ate a biscuit coated } \\
\text { with } \mathrm{LN}_{2} \text {, which then ended } \\
\text { up sticking to her gums. }\end{array}$ & - Cold burns & (13) \\
\hline 13 & $\begin{array}{l}\text { Local Fair - } \\
\text { United States }\end{array}$ & $\begin{array}{l}\text { Improper } \\
\text { handling }\end{array}$ & $\begin{array}{c}\text { Female } \\
-14\end{array}$ & $\begin{array}{l}\text { Subject's thumb came into } \\
\text { contact with } \mathrm{LN}_{2} \text { while eating } \\
\text { her } \mathrm{LN}_{2} \text { infused snack. }\end{array}$ & $\begin{array}{l}\text { - Cold burn on thumb } \\
\text { - Tissue necrosis }\end{array}$ & (14) \\
\hline 14 & $\begin{array}{l}\text { Mall Kiosk- } \\
\text { United States }\end{array}$ & Ingestion & $\begin{array}{l}\text { Male - } \\
\text { N/A }\end{array}$ & $\begin{array}{l}\text { Subject ingested cereal } \\
\text { puffs coated with } \mathrm{LN}_{2} \text { and } \\
\text { blew smoke out his mouth } \\
\text { to appear like a dragon. }\end{array}$ & $\begin{array}{l}\text { - Coughing } \\
\text { - Trouble breathing } \\
\text { - Asthma attack }\end{array}$ & (17) \\
\hline 15 & $\begin{array}{l}\text { Local Fair - } \\
\text { United States }\end{array}$ & Ingestion & $\begin{array}{l}\text { Female } \\
-N / A\end{array}$ & $\begin{array}{l}\text { Subject followed } \\
\text { instructions and ingested } \\
\mathrm{LN}_{2} \text { infused cereal puffs as } \\
\text { directed by employee. }\end{array}$ & $\begin{array}{l}\text { - Second-degree burns and blisters } \\
\text { (roof of mouth) }\end{array}$ & (27) \\
\hline 16 & $\begin{array}{l}\text { Water Park - } \\
\quad \text { Asia }\end{array}$ & Ingestion & $\begin{array}{c}\text { Male - } \\
12\end{array}$ & $\begin{array}{l}\text { Subject was suspected to } \\
\text { have ingested } \mathrm{LN}_{2} \text { while } \\
\text { eating the last few bits of } \\
\text { his } \mathrm{LN}_{2} \text { coated cereal puffs. }\end{array}$ & - $5 \mathrm{~cm}$ gastric perforation & (42) \\
\hline 17 & $\begin{array}{l}\text { Fundraiser - } \\
\text { United States }\end{array}$ & Ingestion & $\begin{array}{l}\text { Female } \\
-N / A\end{array}$ & $\begin{array}{l}\text { Subject ingested a cocktail } \\
\text { containing } \mathrm{LN}_{2} \text { before it } \\
\text { fully evaporated. }\end{array}$ & $\begin{array}{l}\text { - Intense pain } \\
\text { - Fluid and gas build up (lungs) } \\
\text { - Internal cold burns } \\
\text { - Tears or perforations } \\
\text { (esophagus, stomach, and bowels) }\end{array}$ & (24) \\
\hline
\end{tabular}




\section{RISK CHARACTERIZATION}

For this review, qualitative risk estimates were made based on the frequency and types of $\mathrm{LN}_{2}$ injuries reported in the literature from related case reports. These risks are characterized below.

\section{Risk of thermal injury}

In terms of direct skin or tissue contact with $\mathrm{LN}_{2}$, cold burns to the hands or mouth tend to be a commonly encountered injury. The likelihood of cold burns developing is high if direct contact for more than a very brief period of time is made with $\mathrm{LN}_{2}$ itself, the chilled treats, or the serving cups holding $\mathrm{LN}_{2}$. The severity of the injury depends on the duration and extent of contact, and the most serious cases may require amputation. However, the likelihood of this occurring is very low because only a few cases have been reported in the literature $(9,14,31)$.

\section{Risk of inhalation injury}

Generally, when $\mathrm{LN}_{2}$ is inhaled during consumption, health effects are not likely to occur if exposure is minimal and spaces are well ventilated. However, patrons with asthma or other underlying respiratory conditions may be at risk of experiencing an exacerbation of disease following inhalation of $\mathrm{LN}_{2}$.

\section{Risk of ingestion injury}

Consumers are less likely to be injured if the $\mathrm{LN}_{2}$ has completely evaporated before they consume the food or beverage containing $\mathrm{LN}_{2}$ (e.g., ingestion injuries such as gastric perforation would not occur). However, individuals may still experience discomfort or thermal burns due to the cold temperature of the food or beverage (32). On the other hand, if $\mathrm{LN}_{2}$ itself is ingested prior to its evaporation, there is a risk of developing gastrointestinal barotrauma and perforations. In fact, 10 of the 17 cases reported this as the primary injury experienced after ingestion of $\mathrm{LN}_{2}$ prior to its evaporation. However, due to potential publication and reporting bias, perforations are more likely to be reported than other types of ingestion injuries. Therefore, these findings should be interpreted carefully.

\section{DISCUSSION}

There are many potential injuries that consumers may face when consuming foods and beverages containing $\mathrm{LN}_{2}$. Among all the ones discussed, inhalation and ingestion injuries tend to be the most severe because they often result in hospitalization or require surgery. Barotrauma with gastric perforation is the most severe outcome identified. Thermal injuries may also occur; however, their health impact tends to be minor because these injuries usually heal after a few days and do not always require hospitalization. Unfortunately, due to the lack of dietary exposure data available on $\mathrm{LN}_{2}$-infused foods and beverages, it is unknown which age groups are exposed to $\mathrm{LN}_{2}$ the most. Whereas exposure among certain groups will vary depending on the food or beverage being served (e.g., alcoholic or nonalcoholic), children and young adults may be more likely to try treats that are prepared with $\mathrm{LN}_{2}(11,14,21,30,42)$. Based on the case reports reviewed, this age range could be anywhere from 12 to 30 years.

However, note that 4 of the 17 case reports reviewed did not mention age, which could lead to an underestimation of risk for the age groups not accounted for. Therefore, this range should be interpreted with caution.

It also appears from the case reports that adverse outcomes related to $\mathrm{LN}_{2}$ in food may be more frequent in males than females $(2,30,41,43)$. For example, of the 17 cases found in this review, 11 were male and 6 were female. In addition, the most serious outcomes, gastric perforation injuries, were reported in 8 male and 2 female cases. Though the counts are small, it is possible that the higher number of adverse outcomes in males are related to biopsychosocial or environmental factors such as risk-taking behavior and/or peer pressure.

Fortunately, jurisdictions are starting to realize the hazards of $\mathrm{LN}_{2}$ consumption. For example, although the United States does not prohibit the use of $\mathrm{LN}_{2}$ in foods, the U.S. Food and Drug Administration did issue a warning in 2018, advising consumers to avoid such treats (37). Moreover, in Canada, Work Safe British Columbia categorized exposure to $\mathrm{LN}_{2}$ during food preparation as an "emerging risk" to food handlers in 2017 (3). To mitigate such risks, the Ontario Ministry of Labour, Canadian Centre for Occupational Health and Safety, and Work Safe British Columbia published risk advisories and guidelines for how to safely handle the agent in the workplace $(4,28,40)$. In the United Kingdom, a bar was fined after a patron's stomach ruptured and had to be removed following ingestion of a $\mathrm{LN}_{2}$-infused cocktail $(5,30)$. Despite the risks, $\mathrm{LN}_{2}$-infused foods and drinks continue to be served around the world. What is more concerning is that there are now online articles and videos explaining to inexperienced viewers how to make these treats at home $(3,30)$. Thus, to help reduce the risk of injury following consumption of these foods, a list of risk mitigation measures has been provided below for regulatory agencies, vendors, and consumers to consider.

\section{Risk mitigation measures for regulatory agencies}

Although such cases are rare, public health authorities should monitor for cases of injury in relation to $\mathrm{LN}_{2}$ consumption (30). In addition, they should reevaluate its safety whenever new scientific evidence is available (30). To ensure the public is safe from harm, alerts and advisories should be issued when necessary to inform consumers about any potential risks (30). Furthermore, regulators should consider enacting stricter policies with regard to adding $\mathrm{LN}_{2}$ directly to foods and drinks at points of purchase. For example, rather than mixing food and $\mathrm{LN}_{2}$ together in 
one bowl, a safer alternative would be to use two separate bowls. For instance, one bowl can be used specifically for $\mathrm{LN}_{2}$, and another smaller bowl can be placed on top with just the food inside. Having $\mathrm{LN}_{2}$ administered in a separate bowl or compartment from the food can help to prevent the accidental ingestion of $\mathrm{LN}_{2}$. Ice cream made instantly with $\mathrm{LN}_{2}$ should be the only exception to this requirement, as long as the $\mathrm{LN}_{2}$ evaporates before reaching the consumer. Lastly, regulators should only permit the sale of these food products by trained personnel, i.e., those trained on how to properly serve and work with $\mathrm{LN}_{2}$ (30).

\section{Risk mitigation measures for vendors}

Only vendors and employees who are properly trained to handle $\mathrm{LN}_{2}$ should be allowed to prepare or serve $\mathrm{LN}_{2}$ infused foods and beverages to the public (30). Only food grade $\mathrm{LN}_{2}$ stored and served in containers that are specifically manufactured to withstand the thermal effects of $\mathrm{LN}_{2}$ should be used (3). Such containers should have loosefitting lids or safety valves to prevent overpressurization and to reduce the risk of explosion (28). To transfer the $\mathrm{LN}_{2}$, clean flasks specially designed for cryogenic liquids, e.g., a Dewar, should be used (3). When storing, handling, and serving $\mathrm{LN}_{2}$, proper sanitation and hygiene standards should always be followed to prevent bacterial contamination. In addition, employees should always wear appropriate personal protective equipment when handling $\mathrm{LN}_{2}$ (28). Establishments should also have working ventilation and oxygen-monitoring systems installed to detect possible leaks or spills (28). Clear instructions should be provided on how to safely handle and ingest these products when serving customers (3). It is also very important that warnings about the potential dangers of $\mathrm{LN}_{2}$ are posted clearly where consumers can see them (3). Furthermore, utensils and cup sleeves should be provided to consumers to prevent excessive contact with $\mathrm{LN}_{2}$ (3). Finally, bowls should not be served if they contain any residual $\mathrm{LN}_{2}$, and consumers should never be permitted to get refills of $\mathrm{LN}_{2}$ (3).

\section{Risk mitigation measures for consumers}

If children want to consume treats prepared with $\mathrm{LN}_{2}$, an adult should supervise them. As with a hot beverage, patrons should wait a few minutes for their treat to stop steaming or to reach room temperature to avoid thermal injury (33). Before consuming such treats, it is imperative that patrons wait for the $\mathrm{LN}_{2}$ to completely evaporate, i.e., until no more residual $\mathrm{LN}_{2}$ is present (37). Additionally, consumers should never touch the residual $\mathrm{LN}_{2}$ left at the bottom of a serving bowl if present (33). Customers should also blow and fully chew on snacks coated with $\mathrm{LN}_{2}$ to allow the $\mathrm{LN}_{2}$ to fully evaporate before ingestion (33). Waiting for the cloudy vapors to subside and eating the snacks one at a time can also help reduce the risk of injury. If any injury or discomfort is experienced following exposure to these treats, consumers should seek medical attention as soon as possible. In summary, although these foods and beverages can be enticing, the best way to avoid injury is to follow these safety precautions or avoid these treats altogether.

\section{CONCLUSION}

If the trend of adding $\mathrm{LN}_{2}$ to foods and beverages immediately before consumption continues to grow, so will exposure. With increased exposure comes an increased risk of injury to the general public. Although $\mathrm{LN}_{2}$-related injuries appear to be rare, these treats should be handled and consumed with caution because they can potentially result in acute burns, permanent disfiguration, or potentially fatal injuries. Thus, action is needed to inform and educate consumers and vendors about the risks of $\mathrm{LN}_{2}$-infused foods and beverages. In addition, public health authorities may want to consider developing guidelines and/or policies to help reduce the potential risk from these products. Lastly, as identified in the review, there are still many uncertainties regarding the safety of these treats due to the lack of consumption data and oversight. Therefore, further research in this area would be beneficial to help address issues pertaining to evaporation times in different foods and exposure. In turn, this will help guide regulators to put more relevant and targeted food safety interventions into action.

\section{ACKNOWLEDGMENTS}

We express our sincere gratitude to Dr. Kavita Walia for the valuable advice, support, and guidance she graciously offered during this project.

\section{REFERENCES}

1. Balasubramanian, S., M. K. Gupta, and K. K. Singh. 2012. Cryogenics and its application with reference to spice grinding: a review. Crit. Rev. Food Sci. Nutr. 52:781-794.

2. Berrizbeitia, L. D., D. P. Calello, N. Dhir, C. O’Reilly, and S. Marcus. 2010. Liquid nitrogen ingestion followed by gastric perforation. Pediatr. Emerg. Care 26:48-50.

3. British Columbia Centre for Disease Control. 2017. Safety of novel use of liquid nitrogen and dry ice in the food and beverage industry. Available at: http://www.bccdc.ca/resourcegallery/Documents/Educational $\% 20$
Materials/EH/FPS/Food/Safety_Of Novel_Use_of_Liquid_Nitrogen_and Dry_Ice_in_the_Food_and_\%20Beverage_ Industry.pdf. Accessed 23 March 2019.

4. Canadian Centre for Occupational Health and Safety. 2017. How do I work safely withcryogenic liquids. Available at: https://www. ccohs.ca/oshanswers/prevention/cryogens. html. Accessed 8 July 2019.

5. Carter, H. 2015. Nitrogen cocktail destroyed birthday woman's stomach. Available at: https://www.bbc.com/news/uk-englandlancashire-34269286. Accessed 26 June 2019.
6. Centers for Disease Control and Prevention. 2018. 2015-2016 National Health and Nutrition Examination Survey. Available at: https://wwwn.cdc.gov/Nchs/ Nhanes/2015-2016/DR1IFF_I.htm. Accessed 5 May 2019.

7. Chandra, S., and S. D. Aziz. 1994. Leidenfrost evaporation of liquid nitrogen droplets. J. Heat Trans. 116:999-1006.

8. De Solier, I. 2010. Liquid nitrogen pistachios: molecular gastronomy, elBulli and foodies. Eur. J. Cult. Stud. 13:155-170. 
9. Divya, V. C., and B. Saravanakarthikeyan. 2018. Intraoral frostbite and Leidenfrost effect. Aust. Dent. J. 63:382-384.

10. Dutt, A. 2017. Delhi man drinks liquid nitrogen at a bar, ends up with a hole in stomach. Available at: https://www. hindustantimes.com/delhi-news/delhiman-drinks-liquid-nitrogen-at-a-barends-up-with-a-hole-in-his-stomach/ story-Qec1r0Ea84KDk71WIOkhFN.html. Accessed 26 June 2019.

11. Free Malaysia Today. 2016. Teen suffers burns, blisters from Dragon Breath cookies. Available at: https://www.freemalaysiatoday. com/category/nation/2016/12/19/teensuffers-burns-blisters-from-dragon-breathcookies/. Accessed 26 June 2019.

12. Gibbs, W., and N. Myhrvold. 2011. Cryogenic cooking. Available at: https:// www.scientificamerican.com/article/ cryogenic-cooking/. Accessed 23 March 2019.

13. Goh, K. 2017. Dragon's Breath blows into the dessert scene in Singapore. Available at: https://www.straitstimes.com/lifestyle/ food/dragons-breath-blows-into-the-dessertscene-in-singapore. Accessed 26 June 2019.

14. Gonzalez, D. 2017. Liquid nitrogen dessert at fair causing concern for some. Available at: https://weartv.com/news/local/liquidnitrogen-dessert-at-fair-causing-concern-forsome. Accessed 26 June 2019.

15. Gottfried, B. S., C. J. Lee, and K. J. Bell. 1966. The Leidenfrost phenomenon: film boiling of liquid droplets on a flat plate. Int. J. Heat Mass Trans. 9:1167-1188.

16. Government of Canada. 2016. Foodbook report. Available at: https://www.canada. $\mathrm{ca} /$ en/public-health/services/publications/ food-nutrition/foodbook-report.html. Accessed 5 May 2019.

17. Gutierrez, L. 2018. "It seemed harmless enough." Mom, health officials alarmed about Dragon's Breath snack. Available at: https:// www.kansascity.com/news/nation-world/ article215966795.html\#storylink=cpy. Accessed 26 June 2019.

18. Johnson, C. 2015. Thinking outside the liquid nitrogen freezing box. Available at: http:// www.airproducts.com/ /media/downloads/ article/C/en-cryogenic-systems-thinkingoutside-the-lin-freezing-box.pdf. Accessed 23 March 2019.

19. Kernbach-Wighton, G., H. Kijewski, P. Schwanke, P. Saur, and R. Sprung. 1998. Clinical and morphological aspects of death due to liquid nitrogen. Int. J. Legal Med. 111:191-195.
20. Kim, D. H., and H. J. Lee. 2008. Evaporated liquid nitrogen-induced asphyxia: a case report. J. Korean Med. Sci. 23:163-165.

21. Kim, D. W. 2018. Stomach perforation caused by ingesting liquid nitrogen: a case report on the effect of a dangerous snack. Clin. Endosc. 51:381-383.

22. Knudsen, A. R., C. Nielsen, and P. Christensen. 2009. Gastric rupture after ingestion of liquid nitrogen. Ugeskr. Laeger 171:534-534.

23. Koplewitz, B. Z., A. Daneman, S. H. Ein, M. A. McGuigan, and M. Mian. 2000. Gastric perforation attributable to liquid nitrogen ingestion. Pediatrics 105:121-123.

24. Local 10 News. 2014. Woman served "toxic cocktail” at Miami Beach fundraiser. Available at: https://www.local10.com/news/womanserved-toxic-cocktail-at-miami-beachfundraiser. Accessed 29 June 2019.

25. Morales, I., J. Keshavamurthy, N. Patel, and N. Thomson. 2017. Inert gas asphyxiation: a liquid nitrogen accident. Chest 152:A378.

26. National Center for Biotechnology Information. 2004. Nitrogen. PubChem database. Available at: https://pubchem.ncbi. nlm.nih.gov/compound/Nitrogen. Accessed 12 April 2019.

27. Newby, J. 2017. Fair general manager: controversial "Dragon's Breath" concession won't be back next year. Available at: https://www.pnj.com/story/news/ local/2017/10/27/fair-general-managercontroversial-dragons-breath-concessionwont-back-next-year/803757001/. Accessed 26 June 2019.

28. Ontario Ministry of Labour. 2016. Liquid nitrogen in the food and beverage industry. Available at: https://www.labour.gov.on.ca/ english/hs/pubs/ib_liquidnitrogen.php. Accessed 8 July 2019.

29. Pessoa, G. A., M. I. B. Rubin, C. A. M. Silva, and D. C. D. Rosa. 2014. Decontamination of naturally contaminated liquid nitrogen storage tanks. Rev. Bras. Zootec. 43:244-249.

30. Pollard, J. S., J. E. Simpson, and M. I. Bukhari 2013. A lethal cocktail: gastric perforation following liquid nitrogen ingestion. BMJ Case Rep. 2013:bcr2012007769.

31. Roblin, P., A. Richards, and R. Cole. 1997. Liquid nitrogen injury: a case report. Burns 23:638-640

32. Rockswold, G., and D. J. Buran. 1982. Inhalation of liquid nitrogen vapor. Ann. Emerg. Med. 11:553-555.
33. Roustan, K. W. 2018. Dragon's Breath liquid nitrogen snacks may be too hot to handle, mother warns. Available at: https:// www.bramptonguardian.com/livingstory/8799272-dragon-s-breath-liquidnitrogen-snacks-may-be-too-hot-to-handlemother-warns/. Accessed 26 June 2019.

34. Tassou, S. A., J. S. Lewis, Y. T. Ge, A. Hadawey, and I. Chaer. 2010. A review of emerging technologies for food refrigeration applications. Appl. Therm. Eng. 30:263-276.

35. Tedder, R., M. A. Zuckerman, N. S. Brink, A. H. Goldstone, A. B. E. M. Fielding, S. Blair, K. G. Patterson, A. E. Hawkins, A. M. Gormon, J. Heptonstall, and D. Irwin. 1995. Hepatitis B transmission from contaminated cryopreservation tank. Lancet 346:137-140.

36. U.S. Food and Drug Administration. 2018. FDA advises consumers to avoid eating, drinking, or handling food products prepared with liquid nitrogen at the point of sale. Available at: https://www.fda.gov/ Food/RecallsOutbreaksEmergencies/ SafetyAlertsAdvisories/ucm618058.htm. Accessed 23 March 2019.

37. U.S. Food and Drug Administration. 2018. Liquid nitrogen and dry ice in food. Available at: https://www.fda.gov/media/117281/ download. Accessed 8 July 2019.

38. Ventura, G., and L. Risegari. 2010. The art of cryogenics: low-temperature experimental techniques, 1st ed. Elsevier Ltd., Oxford.

39. Walsh, M. J., S. R. Tharratt, and S. R Offerman. 2010. Liquid nitrogen ingestion leading to massive pneumoperitoneum without identifiable gastrointestinal perforation. J. Emerg. Med. 38:607-609.

40. Work Safe British Columbia. 2017. Risk advisory: liquid nitrogen exposure in food preparation. Available at: https://www. worksafebc.com/en/resources/health-safety/ risk-advisory/liquid-nitrogen-exposure-infood-preparation?lang=en\&direct. Accessed 8 July 2019.

41. Yaegashi, Y., F. Nakajima, N. Hosoi, H. Fukuta, and M. Sase. 2000. Case of gastrorrhexis caused by ingestion liquid nitrogen. Jpn. J. Gastroenterol. Surg. 33:1648-1651.

42. Yonhap News Agency. 2017. Liquid nitrogen treat forms hole in boy's stomach Available at: https://en.yna.co.kr/view/ AEN20170803011000315. Accessed 26 June 2019.

43. Zheng, Y., X. Yang, and X. Ni. 2018. Barotrauma after liquid nitrogen ingestion: a case report and literature review. J. Postgrad. Med. 130:511-514. 


\section{APPENDIX}

Appendix A. Search strategy used to obtain scholarly literature

\begin{tabular}{|c|c|c|c|}
\hline Database & Search no. & Searches & No. of records retrieved \\
\hline \multirow[t]{31}{*}{ Ovid MEDLINE } & 1 & Liquid nitrogen.m_titl. & 1,131 \\
\hline & 2 & drink*.ti,ab. & 166,416 \\
\hline & 3 & beverage* $. t i, a b$ & 29,904 \\
\hline & 4 & Cocktail*.ti,ab. & 12,792 \\
\hline & 5 & 2 or 3 or 4 & 200,404 \\
\hline & 6 & 1 and 5 & 4 \\
\hline & 7 & Ingestion*.ti,ab. & 83,008 \\
\hline & 8 & Consumption*.ti,ab. & 336,607 \\
\hline & 9 & Inhalation*,ti,ab. & 75,211 \\
\hline & 10 & 7 or 8 or 9 & 483,165 \\
\hline & 11 & 1 and 10 & 15 \\
\hline & 12 & Ice cream*.ti,ab. & 1,557 \\
\hline & 13 & Snack.mp*.ti,ab. & 8,856 \\
\hline & 14 & 12 or 13 & 10,313 \\
\hline & 15 & 1 and 14 & 1 \\
\hline & 16 & Injury*.ti,ab & 826,458 \\
\hline & 17 & 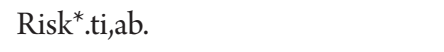 & $2,802,356$ \\
\hline & 18 & Danger*.ti,ab. & 75,029 \\
\hline & 19 & Effect*.ti,ab. & $8,089,620$ \\
\hline & 20 & 16 or 17 or 18 or 19 & $10,564,240$ \\
\hline & 21 & 1 and 10 and 20 & 9 \\
\hline & 22 & Barotrauma*.ti,ab. & 3,090 \\
\hline & 23 & Gastric perforation*.ti,ab. & 1,429 \\
\hline & 24 & Airway perforation*.ti,ab. & 2 \\
\hline & 25 & Pneumoperitoneum*.ti,ab. & 8,922 \\
\hline & 26 & 22 or 23 or 24 or 25 & 13,286 \\
\hline & 27 & 1 and 26 & 10 \\
\hline & 28 & Asphyxiation*.ti,ab. & 1,287 \\
\hline & 29 & 1 and 28 & 2 \\
\hline & 30 & Death*.ti,ab. & 995,469 \\
\hline & 31 & 1 and 30 & 11 \\
\hline Google Scholar & 32 & Gastrorrhexis and liquid nitrogen & 15 \\
\hline Web of Science & 33 & Liquid nitrogen and frostbite & 21 \\
\hline TOXNET & 34 & Liquid nitrogen & 4,204 \\
\hline
\end{tabular}




\section{Appendix B. Websites and databases used to obtain gray literature}

Source

Ontario Ministry of Labour U.S. Food and Drug Administration

British Columbia Centre for Disease and Control

Work Safe British Columbia

Government of Canada

Canadian Centre for Occupational Health and Safety

Centers for Disease Control and Prevention

National Center for Biotechnology Information

Local 10

Free Malaysia Today

The Standard

Pensacola News Journal

Yonhap News Agency

Kansas City Star

ABC WEAR-TV

The Straights Times

Scientific American

Hindustan Times

Air Products
Title

Liquid Nitrogen in the Food and Beverage Industry

a) FDA Advises Consumers to Avoid Eating, Drinking, or Handling Food Products Prepared with Liquid Nitrogen at the Point of Sale

b) Liquid nitrogen and dry ice in food

Safety of novel use of liquid nitrogen and dry ice in the food and beverage industry

Risk Advisory: Liquid nitrogen exposure in food preparation

Foodbook Report

How do I work safely with - cryogenic

National Health and Nutrition Examination Survey

Nitrogen

Woman served "toxic cocktail" at Miami Beach fundraiser

Teen suffers burns, blisters from Dragon Breath cookies

Dragon's Breath liquid nitrogen snacks may be too hot to handle, mother warns

Fair general manager: Controversial “Dragon's Breath” concession won't be back next year

Liquid nitrogen treat forms hole in boy's stomach

"It seemed harmless enough." Mom, health officials alarmed about Dragon's Breath snack

Liquid nitrogen dessert at fair causing concern for some

Dragon's Breath blows into the dessert scene in Singapore

Cryogenic cooking

Delhi man drinks liquid nitrogen at a bar, ends up with a hole in stomach

Thinking outside the liquid nitrogen freezing box 